Terbit online pada laman web jurnal : http://e-journal.sastra-unes.com/index.php/JIPS

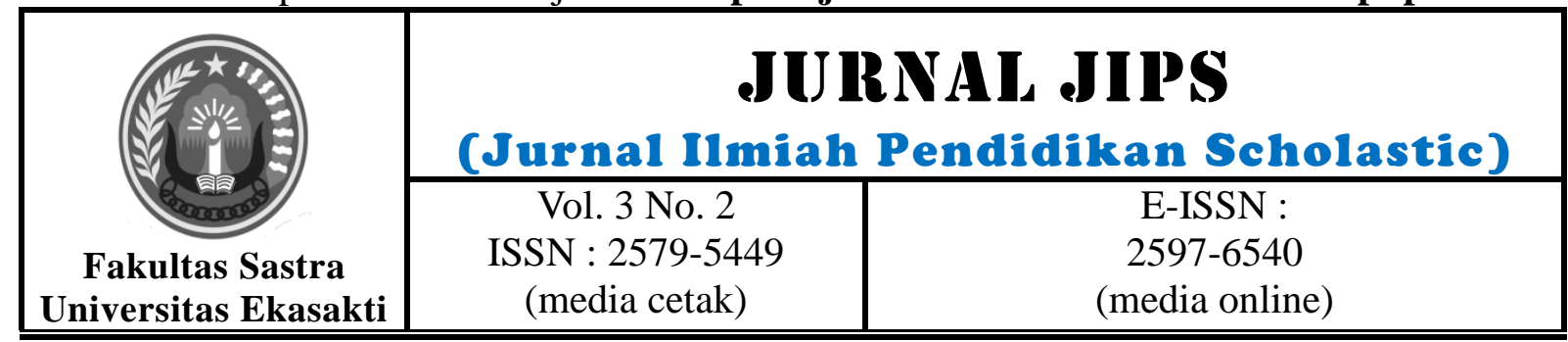

\title{
AN ANALYSIS OF TEN SYMBOL OF GRANDMA DEATH AS REFLECTED IN THE EDWARD ALBEE SANDBOX
}

\author{
Yulia Sari, Amelia Yuli Astuti \\ Fakultas Sastra Universitas Ekasakti \\ *Corresponding Author: Amelia Yuli Astuti \\ Fakultas Sastra Universitas Ekasakti
}

\begin{abstract}
This research is entitled An Analysis of Ten Symbol of Grandma's Death As Reflected In The Edward Albee Sandbox. Where in the short story the 85-year-old grandmother who had been left by her husband and after the death of her husband the grandmother fought alone to support her child 'namely mommys. But the child that grandmother hoped didn't care about him. Mommy treats grandma very inhumanely. He put my grandmother under the kitchen and only had a thin blanket and used potluck utensils. Then mommy took grandma to a place and put her in a sandbox where I interpreted this as the last time for grandmother's care and that was very tragic, like waiting for grandmother to die so they could live in peace. They did not care about mommy until mommypun died. This research aims to : (1) To explain the reader understand the extrinsic elements of The Sandbox drama. (2) To explain the reader understand and be able to describe what symbols are used from the drama The Sandbox. (3) To analyze the absurd symbols of The Sandbox drama.

This study uses the theory of Roland Barthes who put forward a sign or symbol and a little supporting theory from Saussasure. The method used in this research is descriptive analysis method and qualitative method, which is describing the collected data and then compiled it by analyzing a semiotic drama script which can be seen from its extrinsic elements that have absurd symbols. Based on the results of this analysis it can be said that in this analysis the writer found ten absurd symbols contained in the sandbox drama. From the results of this analysis there is also a picture of the theme raised for this drama is about the emptiness, emptiness, and loneliness of a person in which we as humans need love and affection from other humans.
\end{abstract}

Keywords: Absurd, Symbol, Symbol Absurd of Grandma Death

(C) 2019Jurnal JIPS

\section{INTRODUCTION}

Absurd is the flow of modern literature which views life as irrational, uncertain, full of contradictions and chaotic. This school of thought assumes that the norms used by humans do not have a strong basis.

Drama has a supporting element that is : intrinsic elements and extrinsic elements. The instrinsic element is theme, plot, background, figure, point of view, stage, and symbols.Extrinsic element is the outer element that influences the literary works. In this writing, the extrinsic element discussed is absurdism.

Here are some understanding of drama according to experts : 
1. Luxemburg, drama is a literary work which in the writing of its text cointains dialogues and its contents unfolds a plot. Like fiction, the drama centers on one or more of the main characters who successfully enjoy their roles or endure the failures they will encounter later as a challenge and confront other actors.

2. Budianta, drama is a genre of literary works whose physical appearance shows verbally the existence of dialogue or conversation among existing figures.

3. Team Matrix Media Literata, drama is a narrative form that describes the life and nature of human beings through interactions (acting) that are staged.

The absurd drama was first shown in the 20th century. Absurd is a modern literary literature that views life as irrational, uncertain, full of contradictions and chaos. Some writers such as Samuel Becket, Eugene Ionesco, Arthur Adamov, and Edward Albee are literary writers who often use absurd flow in their literary works. One of the most famous actors of the flow of absurd is Albert Camus. Edward Albee presents an absurd drama with a different perception of the treatment of the deceased. The tragic and sad impression is still there but served in a different way. Other features in the drama written by Albee include the use of music and lighting.

Albee is contrary to the absurd meaning through the many symbols he shows in his absurdity drama. Symbols function to convey the meaning contained in a set of artist ideas. The types of symbols in drama are basically only three, namely visual, verbal, and auditive symbols.Background problems provide reasons for problems in this analysis. Therefore, the author begins by describing facts, problems, and solutions for this writing. The fact in this analysis is an absurd symbol found in grandma's death.

The drama begins in bright daylight, located on a beach, where a man is doing a body workout. Near the man, there is a sand sand box that is in the center of the stage, on the left side of the stage there is a chair and place stands pemusic, then on the right side of the stage there are two empty seats. Then Mommy and Daddy entered the stage, talked for a moment, then Mommy greeted the young man. Then they bring Grandma and put it on the sandbox. Mommy waves his hand to the boy. They took Grandma to the beach to do their last treatment in delivering Grandma to the Almighty. They spent the whole day at the beach in anticipation of Grandma's death. They have been taking care of it since Grandma lived with them in the city, after decades of life in the village and her husband's husband's farm since she was 30 years old. But since her daughter married a rich man, Mommy became more disobedient.

She treats her parents as rubbish at her home, putting Grandma under the kitchen, sleeping with a thin army blanket, and always eating with the same equipment alone. Mommy did not put Grandma in the Nursing Home as the family in America did. In addition to the four of them, there is an actor who has a duty as accompaniment of death, the Musician. He never talks to anyone, just nods when told to play his music. Mommy and Daddy had a conversation. Daddy just followed Mommy's will. When entering the stage Mommy allowed the Musicians to enter the stage, play and dismiss the music. Grandma shouted like a fussy child, playing spades and buckets over a sandbox. Mommy told Grandma to stay calm 'face death' that will soon pick her up. Then grandma pours out his heart, telling how painful her life journey is. Married at a very young age of 17 years, then her husband died when she was 30 years old, leaving a girl and a farm. All he manages and manages himself. Then Grandma lives with her child and his son-in-law in the city. The conversation between Grandma and the young man began when the Grandma realized there was a handsome young man next to him. She started asking questions about the young man and joking with him.

Next, Grandma starts telling her about her life experiences while living with her daughter in town. Then the day turned into night, Mommy thought it was the moment Grandma would die. With his excessive style he cried, as if sad for Grandma. But Grandma says that she is not ready to go yet. momy commented that after Grandma's death they would end the sadness, then continue their lives and face their future. The Grandma was silent on Mommy's comment. Because $\mathrm{He}$ knew what Mommy meant, that their lives would be calm without the 'distractions' of Grandma that had been their responsibility all these years. Day went into the afternoon. Then Mommy and Daddy left the stage. 
While on the beach Grandma often do strange things like playing a shovel and a bucket and then demonstrate the movement like burying himself with sand. While chatting with the Youth. Shortly afterwards the young man kissed Grandma's forehead, then confessed that he was doing "treatment" for Grandma's death, he confessed that he was an angel of death.

\section{RESEARCH METHOD}

The writer divides the method of research into the method of collecting data, method of the data analyzing procedure, technique of data collecting, and technique of the data analyzing procedure. This method provides the steps of writer in collecting and analyzing the data.The writer choose the type of research is descriptive qualitative. Qualitative research is research that is used to examine the condition of natural objects, where researchers are key instruments (Sugiyono, 2011). This study uses qualitative data where this research is often used and carried out by a group of researchers in the field of social sciences, including education. According to moleong (2005) said the characteristics of qualitative research use qualitative methods, namely observation, interviews or document reviewers.

Qualitative research is carried out to build knowledge through understanding and discovery. Qualitative approach is a research process and understanding based on methods that investigate a social phenomenon in human problems, in this study the researcher makes a complex picture, examines words, detailed reports and views of respondents and conducts studies in natural situations. This research was carried out in natural and inventive conditions. In this study, researchers were key instruments. therefore researchers must have a broad theory and insight.

\section{Method of Collecting the Data}

The data collecting procedures is focused in the process of the writer collect the data. In the collecting data the writer uses a qualitative approach. A qualitative approach can be in the form of opinions, responses, information, concepts and information in the form of descriptions in expressing problems.
Although Grandma was surprised he was ready, and praised the Youth's treatment very well and lovingly. Soon after, Grandma died. Grandma feels affection at the end of her life, when the Youth can make her a human being who is considered her existence and grievance, and takes her life by kissing her forehead.

Whereas qualitative research is only a process of filtering data or information that is not too deep about a problem. To collect data, the author looks for data sources. Data sources are " drama scripts" that will be used as research objects.

\section{Method of Analyzing the Data}

In analyzing the data, the information from data collection is processed and presented in form of thesis. In the application, the writer uses semiotic approach. Semiotic approach is one approach that is quite important and widely used. This approach invites us to understand the work of caste through signs.

Structuralism is a method that has been referred to by many semiotics. This is based on De Saussure's structural linguistic model. Structuralists try to describe the sign system as language. They work to find the deep structure of the form of a structure (surface structure) a phenomenon. Contemporary social semiotics have moved beyond structural attention, namely analyzing the internal relations of parts with a self contained system, and trying to develop the use of signs in specific social situations. The services of two semiotics that cannot be forgotten are Ferdinand De Saussure and Charles Sanders Peirce, because the subsequent development of semiotics was greatly influenced by these two experts. Saussure developed his semiotics based on European linguistics, while Pierce based philosophy. If you pay attention there are differences in views from both. Saussure tends to question the "inner structure" of the signs by showing the marking process in the diadik system, namely signifier and signified. A signifieris associated with a signified in the form of a concept and the concept is something that is in someone's mind, so it does not need to be associated with reality.In contrast to what 
Peirce conceptualized in the marking process.

Peirce is famous for its triadics, namely representamen, objects, and interpretants.

Representaments function as markers and objects as markers, but functional relations occur only when they are interrelated by interpreters. Peirce acknowledges the existence of objective reality which plays a role in the formation of signs.

Barthes developed the Saussure view at the stages of the marking process. Marking is (Barthes, 2012: 43), the act of binding a signifier with a signified, an action whose result is a sign. Furthermore, Barthes (2012: 27-50), states, in the Saussurean termenilogy, signifier and signified are components of signs. To test an 'sign on its own ', which is to deal only with the relationship between a signer and a sign, is an arbitrary abstraction. Signs are no longer according to their compositions, but by taking into account the things that are the background of their existence. This is a matter of value. Value is closely related to the concept of language.

\section{Technique of Collecting the Data}

Technique of Collecting the data are the most important step strategic in research. In this research the researcher is using note cards. The researcher noted dialogue that corresponded to the problem.

\section{Technique of Analyzing the Data}

The data analysis procedure relates to the way the writer conducts data analysis. After collecting the data, the researcher classify data according to the symbols that are going to analyzed. Each category of the data will be analyzed by interpreting each data.

The research selected the short story carefully, the are many good short story the researcher chooses short story by Charlotte Perkins Gilman's "The Yellow Wallpaper", William Faulkner's "A Rose For Emily", Kate Chopin "The Story Of An Hour".
1. Read the short story to convince about the story.

The researcher was read the short story by Charlotte Perkins Gilman's "The Yellow Wallpaper", William Faulkner's "A Rose For Emily", Kate Chopin "The Story Of An Hour".

2. Writing the title of the research is the depressed female characters from their intimidated surrounding as seen in Charlotte Perkins Gilman's "The Yellow Wallpaper", William Faulkner's "A Rose For Emily", Kate Chopin "The Story Of An Hour"

The data is taken from the script of three short story by Charlotte Perkin Gilman's "The Yellow Wallpaper", William Faulkner's "A Rose For Emily", Kate Chopin "The Story Of An Hour" with psychological-feminist theory.

\section{Technique of Analyzing the Data}

After data collection, the specific steps that writer must take in this research are as follows:

1. Identifying the depressed female characters. The research identified the depressed female character in the short story from analysis by Charlotte Perkin Gilman's "The Yellow Wallpaper" , William Faulkner's "A Rose For Emily", Kate Chopin "The Story Of An Hour".

2. Classifying data from the dialog of the scrip analysis by Charlotte Perkins Gilman's "The Yellow Wallpaper", William Faulkner's "A Rose For Emily", Kate Chopin "The Story Of An Hour" which containing psychological-feminist analysis.

3. Describing the distribution of the use of psychological-feminist analysis in the short story entitled Charlotte Perkins Gilman's "The Yellow Wallpaper", William Faulkner's "A Rose For Emily", Kate Chopin "The Story Of An Hour".

4. Analyzing and interpreting female character with psychological-feminist by Sigmund Freud and Maggie Humm.

Drawing the conclusion from the data analysis and giving suggestion.

\section{RESULTS AND DISCUSSION}

In this chapter IV will discuss the result of research and discussion about the Sandbox drama. This drama was written by Edward

will analyze this drama from three things namely : extrinsic elements, symbols used, and absurd symbols. which there are absurd symbols in it. The writer 


\section{Extrinsic Elements the Sandbox}

In this section we discuss the extrinsic elements of the drama The Sandbox which include elements of absurdism. Absurdism in The Sandbox Seen's drama from the beginning of this drama. The Sandbox is an absurd drama, it doesn't make sense in its delivery and the things that happen in it. The main theme of this drama is the void of life. Its reliability starts with a stage concept that shows the void of stories in the drama. Starting from the elements found on the stage that show the emptiness of each actor, the storyline is dynamic, sad but delivered as leluncon, as well as a lighting system that gives a dramatic impression. Set the stage on the beach and show it on a clear day. The time marker here is also an element of dramatization the sandbox drama.

On the stage there are two empty chairs on the left side of the stage. This chair will be used for Mommy and Daddy, this chair symbolizes the emptiness of their lives as a married couple. Then in the middle of the stage there is a sandbox which in the drama is absurd the likeness of a coffin for the Grandma (grandmother). Then there is a chair along with the music stand that is used by the Musician later. A young man dressed as a coast guard carrying out the Chalistenic movement. This young man is the Angel of Death. The absurd theme that dominates this drama can be seen from the storyline. Through this drama, Albee said that "tradition" is absurd which will contain impossibility, delinquency, sadness, madness, pain but delivered beautifully and provide comfort in accordance with the tragic. Void life (delinquency) is the main theme in this drama, because the emptiness of the meaning of the role of parents in the eyes of children is also included in the theme. From the whole theme of the drama The Sandbox about meeting mom and dad for the death of their grandmother they wanted. This treatment is almost the same when grandmothers still live and live in their homes. Like putting it under the stove (kitchen) and providing special equipment for grandma. Other players such as Youth and Musicians also included people who also did "care" specifically for grandma, but through help that was different from Mommy and Daddy.

The concept of family life in America is a family that exists only consists of parents and children without other family members such as those found in families in Indonesia. More personal to a family, family will be better. Responsibility for conditions and household needs is fully fulfilled. Then the concept of care for parents in America, where parents have to live in nursing homes or in their own homes rather than living in the homes of their children. As in concept, it shows Grandma's emptiness. The absurdity of Grandma's life and her worthless existence were also found in this drama. Although at the end of his life he got the love given by the young man even though he was the angel of death, who kissed his forehead. This shows the tenderness of death that was delivered at the beginning. "Care" specifically for grandma, but through a different treatment from Mommy and Daddy.

\section{SYMBOLS}

Symbols are signals or signs are used to represent something else such as the quality of abstraction of ideas and objects. In Wellek and Warren's book "Literature Theory", such as "image" or "imagination" which gave birth to the flow of imagination, "symbol" also gave birth to a literary genre, namely symbolism. Symbols appear in very diverse contexts and are used for various purposes. The same element in diverse uses as in literature is the symbolic nature of representing something else. But in the word symbol there is actually a Greek verb element which means to mix, compare, and make an analogy between the sign and the object being referred to. According to literary theory, symbols should be used in the following sense: as objects that refer to other objects, but also require attention to themselves as an embodiment (1990, 239-240).

As quoted in the book Wellek and Warren, according to Coleridge the symbol is: Characterized by the appearance of traits which characterize species in individuals, or general traits in particular, by the appearance of things which are eternal in temporary matters (1990: 240).

Kennedy stated in his book about symbols: Symbol in literature is a thing that suggest more than its literal meaning. Symbol generally did not "stand for" only one meaning, nor for anything 
absolutely definite; they point and hint. A symbolic act is a gesture with larger significance than usual (Kennedy, 1991: 145-147).

In accordance with some of the definitions of the symbol above, the author can conclude that the symbol is an image of something, can be interpreted literally or double meaning. In general, symbols do not 'stand alone' on only one meaning, but for other meanings that really have a definite meaning they refer and direct to the true meaning. The role of a symbol is a movement with a broader understanding than usual.

Paul Ricouer in his article entitled "Symbolism", "all symbols speak of the situation of human existence in its existence in the world. His job then is to reap from the symbol and elaborate the existentialist concept. Good symbolism can be interpreted with thoughts that are not only rational, but also meditative or contemplation, if the reflection is lost then it is no longer a symbol giving meaning to us if we think and interpret it.

In absurd dramas symbolizing something is its characteristic. Whether realized or not by the reader/audience. The purpose of the symbolization is certainly to describe the condition of the story and the characters in it. Forms of the use of symbols are not only in the stage, the costume of the player, the naming of characters, and the setting of the story, but also in the dialogues. The existence of certain purposes in absurd drama, therefore the symbolism in absurd drama is always used in this drama. Not only conveying messages in the form of stories and supporting components, the use of symbolism is also a form of insinuation of the subject to be addressed in the drama. In absurd drama symbols are things that support the absurd theme that has been carried since the beginning of writing. Unusual symbols are the main things that can be interpreted by each reader or audience

In drama the sandbox there are types of symbols like :

Visual symbols are symbols that are visible in the viewer's view. Visual symbols contain all shapes and colors including the player's body. Everything that appears on the stage will send a message of meaning to the audience. For example, a player who plays a certain character is a symbol of the director's character. Starting from gestures, costumes, and supporting tools on the stage. Lighting will also increase visual symbols, such as light, dim, red, orange, yellow, blue and so on. The behavior of all players, the shape and color of objects will give the audience a symbolic impression. Example : stage layout simbols, the sandbox,buckets and shovels,etc.

Auditive symbols are symbols that sound or symbols caused by sound. Every sound always has meaning and every note always has meaning in drama. Because all sounds, tones, lyrics and songs are deliberately made to strengthen communication. the voice of the character's compilation is angry, or the sound of a step like someone marching on a symbol to impress something. A serene song in a romantic scene is also a symbol that will support the requested scene. Example : Symbols of the function of the Musician as Accompaniment of Death. In this study the author uses visual symbol and auditive symbol. Because of the sandbox drama symbols are displayed through objects, music, light. This symbol is categorized as significant and signified. These two components can't be separated. Significant is the image of a impression that appears in our minds. Whereas signifie is an understanding or impression of the meaning that is in our mind. So the symbols contained in the drama have meanings that arise from our minds and how we explain the impressions of that meaning.

\section{Absurd symbol}

Absurd is the flow of modern literature which views life as irrational, uncertain, full of contradictions and chaotic and Symbols are signals or signs are used to represent something else such as the quality of abstraction of ideas and objects. Absurdism is a philosophy born of existentialism, regarding the philosophical concept of "Absurd", a dispute between human tendencies to perceive several notions related to the universe and humans who look at the discovery of the meaning of life.

According to Kanzunnudin in his book entitled Dictionary of Terms 
Drama, absurdity is something that is unreasonable, absurdity, and something odd. While according to him absurdism is the flow that states that the world is neutral, reality and events are not realized. There is no objective truth. Every human being finds his or her own life values. As far as he accepts that the value he found is actually absurd. (2003: 27)

He explained further about absurd drama; human actions that view something immoral cause moral or immoral actions have the same position then it can be said that the norms used so far are absurd. The contents of this drama are chaos both in terms of flow journals, dialogues that are often not related to other characters (overlapping dialogue) and are full of punctuation, characters, and time full of chaos. The absurd has existed since the end of World War I, along with the emergence of Dadaism and Surrealism. After World War II and along with advances in science and technology, absurdism was fully realized. Especially in the field of centrality as set forth in drama and fiction. The interesting thing about the portrayal of rebellion about absurdity is about rebellion, freedom, awareness, and feelings of innocence. This is because humans realize that the world and life are irrational.

Whereas on the other hand he wants universal freedom. It is this awareness that leads to an understanding of absurdity, so that humans do not believe anything else other than reality here and now. He is human today. Humans like this know that their lives are not a matter of how to explain and solve, but experience and describe. In Siswo Harsono's book About AvantGarde, absurd theater is a term applied to certain European and American play wrights in the 1950 s and early 1960s borrowed from the existentialist philosophy of Albert Camus, in his essay entitled The Mythe of de Sisyphus , first defined the human situation which is essentially "absurd". Language in absurd plays is often misplaced, full of technical jargon, cliches, and repetitions. (2000: 97-98).

Quoted from Siswo Harsono's book entitled About Avant-Garde:

$$
\text { According to Ousby, }
$$

Theater absurd literally means "out of harmony", absurd is Albert Camus's appointment to the situation of modern humans, strangers in an inhuman world. Whereas Martin Esslin defines the Absurd Theater as a theater that presents an absurd presence of human existence in a dramatic style that deviates from the normal that reflects the circumstances. Certain techniques used by absurd writers, however, have established themselves in contemporary theater, and in this formal sense, rather than in philosophical terms, the idea of an "absurd theater" has maintained the circulation of critical values.Techniques in the form of broken form related to farce, but there is no prior harmony context to provide a guarantee back to an audience. Indeed there is extraordinary concrete, separate from the environment that formally limits it. (2000: 98-99)

Absurdism has many elements that can influence and provide themes in a literary work. In writing this thesis, the author only gives a few elements, namely: Absurdity is the most widely and frequently developed theme in absurd drama. The characteristic of absurdity is that the world no longer has a sense of the people around it, where decisions made on a ratio basis are decided with the impossible and all the actions are meaningless and fail. Validity can also be explained from the various situations and events contained in the drama associated with the movement (Beacham, 2007: 2).

Crime and Violence. Aside from the nonsense and humor that slapstick in Absurdism there are hidden elements of violence, often appearing in divisions between characters, but sometimes appearing in actions that display violence. For example in the drama Harold Pinter In The Room, blind people brutally beat (Beacham, 2007: 2).

Nothing in life. People who live in nothingness will feel what is called emptiness. He considers that his life is meaningless, futile or meaningless. Living in a Sociological perspective is an isolated 
life. Then it can be said that alienation in life is a proof of nothingness in life. Nothing in the real world also means emptiness in everything, including life without purpose and meaning.

Vain (failure) and ignorance (passive). The failure of all human endeavors in their characterization is abundantly found in works concerned with absurdism. Like one of Samuel Beckett's works, Waiting for Godot, gives the impression that human efforts are meaningless and endless until the end of the story. Beckett's character was very ineffective and caused failure that they could not do but committed to suicide successfully compared to their efforts. Their passivity, built on endless waiting, illustrates this very well in the cover of both the first and second rounds, where each position stems from the point of its existence on stage despite having the decision to leave the stage (Beacham, 2007: 3).

In absurd drama, the symbols of something is its characteristic whether it is realized or not by the reader or the audience. The purpose of the symbols is to describe the condition of the story and the characters in it. Symbols are used not only stage, Player costumes, character names and story settings but also in dialogue. There are certain goals in an absurd drama. Therefore, symbolism in absurd drama is always used in this drama. Not only conveying messages in the form of stories. . The use of symbolism is also a form of satire for the intended subject. In this drama the absurd symbol is something that supports the absurd theme that has been done since the beginning of writing. drama :

Some absurd symbols in the sandbox

\section{Stage layout symbols}

The meaning of the stage in this drama is the emptiness of the lives of the player, especially grandma. On the stage there is a complete sand box with a bucket and the shovel is in the middle of the stage, then two chairs on the right of the sandbox, then a chair and music stand for the musician. The setting is on the beach. There are territorial constraints that take the most important role in drama, namely the beach.

The beach is a limitation of life from grandma. In this drama, death is considered a child's play and there is no scary value. This is to disguise the meaning of absurdism which is always terrible and sad. The other emptiness of the symbol is shown from two chairs which show the emptiness of the marriage life of the mother and father. This is evident from Father's repeated dialogues with Mommy, but not noticed by grandmothers, as well as their daily lives. This drama is also a reflection of life married Mommy and Daddy. Where the position of women (Mommy) is higher than that of men (Daddy) who is none other than the head of the family. And the Daddy who also shows a lazy attitude to debate arguments with his wife. There is a point of saturation of life in his life. the lack of passion in his household life also affected Daddy's psychology itself.

THE SCENE. A bare stage, with only the following: Near the footights, far stageright, two simple chairs set side by side, facing the audience; near the footlights, far stage-left, a chair facing stageright with a music stand before it; farther back, and stage-center, slighly elevated and raked, a large child's sandbox with a toy pail and shovel; the background is the sky, which alters from brightest day to deepest night.

Another thing that reflected their emptiness was the absence of a name for Mommy and Daddy. the two figures only called each without mentioning their names. From the obscurity of Daddy and Mommy's name, it means that the two characters do not have compassion as a couple who have been married. their lives are only in the form of emptiness, there are no holidays, romance, or children as a complement to their lives. 


Note. When in the
course of play, MOMMY
and DADDY cal each other
by these names, there
should be no suggestion of
regionalism.
These names are of empty
affection and point up the
pre-senility and vacuity of
their character.

\section{The sandbox.}

The sandbox here is interpreted as a coffin, where Grandma was put on top of it and made a motion to bury herself and died in that place. Maybe the audience of this drama does not understand why the stage setting is on the beach and there is a sandbox indeed, it is generally on the beach. This is precisely the location of the validity and of the drama The Sandbox, the reader/audience will be fooled at first, but over time the reader/audience will understand the meaning of the sandbox itself which is the title of this absurd drama.

\section{GRANDMA is discovered, still in the sandbox, lying on her side, propped up on an elbow, half covered, busily shoveling sand over herself.}

\section{Buckets}

Where the equipment is used in funeral ceremonies to bury. In this case the function of the object can be interpreted literally as its function, because Grandma buried herself using the tool. The grandmother indirectly interpreted the use of the tools to the reader or audience, whether they realized or not.

GRANDMA (muttering. I don't know how I'm supposed to do anything with this goddam toy buckets.

\section{Shovels}

This equipment has the same meaning as a buckets.This equipment is also used by grandmother in drama. Which is used to bury yourself because grandma feel hopeless and disappointed with her daughter who doesn't care about her.The equipment used by this grandmother is also like explaining that grandma wants to get away from this world quickly, because she feels lonely and despair makes her not have the spirit to live.

GRANDMA (muttering. I

don't know how I'm supposed to do anything with this goddam toy shovels.

\section{Sand means burial itself}

Maybe the reader/audience does not care about the function of the sand itself, because it is 'fooled' by the stage setting which is on the beach. The deceased person can be buried in various ways such as buried, the grandmother continues to pour her body of sand as a form of burial of her death which is always awaited during the end of her life.

GRANDMA: Ah-haaaaaa!
Graaaaa! (Looks for reaction;
gets none. Now . . . directly to
the audience) Honestly! What
a way to treat an old woman!
Drag her out of the house . .
stick her in a car . . bring her
out here from the city . . .
dump her in a pile of sand . . .
and leave her here to set. I'm
eighty-six years old! I was
married when I was seventeen.

\section{Symbol of Lighting Game}

Edward Albee always uses lighting in his drama as a form of dramatization effect.Here is, lighting used as a sign of darkness over the death of grandmother who will come soon, but it is only a dramatic marker not a marker of the death of grandmother later. Because the grandmother did not die in a tense and tragic atmosphere. But in the afternoon with a kiss on his forehead. However, behind all that lighting here is also still used as a time marker such as changing days and players' emotional markers. Dramatization things like this that embellish the inner beauty drama. 
GRANDMA. Don't put the lights up yet ... I'm not ready; I'm not quite ready. (Silence) All right, dear. . . I'm about done. (The lights come up again, to brightest day.

\section{Grandma's Symbol Burying Herself with Sand}

My grandmother wanted to give her life by burying herself with sand even though mom and dad wanted more. She wants to finish her sadness alone, the emptiness of money that does not mean in the eyes of her own daughter. After being explored further, expanding family members with young people and spectators, together indirectly, they did not create togetherness with God. They will spend a long time, where he is at the age of 31 years, and create the lives of children. own woman. Plus massage, children who say, love them themselves, who have struggled to raise them. The treatment that comes in vain form for the whole struggle first. He assumed that God did not help him and instead called a pictorial life, even though he had never 'complained' anything for what he had lived during the photo.

GRANDMA. Ah-
haaaaaa! Graaaa! (looks
for reaction;
gets none; Now . .
directly to the audience)
Honestly! What a
way to treat an old
woman! Drag her out of
the house. . stick her
in a pile of sand. . and
leave her here to set. I'm
eighty-six years
old! I was married when I
was Seventeen. To a
farmer. He died
when I was thirty. (To the
Musician) Will you stop
that, pleae?
(The Musician stops
playing.) I'm a feeble
woman . . how do you
expect anybody to hear me
over that peep! Peep!

Peep!

(To

herself) There's no respect around here. (To the Young Man) There's no respect around here.

\section{The symbol of Grandma's reality is buried before she dies}

The burial of Grandma as a symbol of her being buried alive interpreted her burial as a human being who was not yet time to die but was 'forced' to die in a certain way. Supported also his desire to immediately end his life, because he was fed up with his life especially after he moved to the city and was wasted by her son.

\section{GRANDMA is discovered, still in the sandbox, lying on her side, propped up on an elbow, half covered, busily shoveling sand over herself.}

\section{Symbols of the function of the Musician as Accompaniment of Death}

The musician is one of the actors who built the atmosphere and actually this is one of the distinctive features of the drama Albee who always uses music as his drama. He is an actor in this drama who never speaks, only nods when told to play or stop playing his guitar. From the beginning to the end of the musician's story always accompanies sad songs for every event and dialogue between players. he is also the accompaniment of death. In this case it can be said he knew Grandma's impending death later. Even though he is part of Grandma's death his role in this drama is still nil, nil from the point of view of an actor. Because this is included in the absurd drama section, where on the beach there is a musician assigned to 'accompany death' Grandma. But this peculiarity can be seen through ordinary burial methods by Christians, Batak people, Borneo people, and so on who sing certain death songs at each person's funeral. Be it relatives or other people. But of course the music that was delivered specifically for the funeral process itself usually contained prayers offered specifically for those who died. Whereas in this drama, the musician is just playing a song with his acoustic guitar. His role is just playing the instrument with a melancholic song that can 
create a dramatic atmosphere, not giving a song that is a special song for death as it is usually sung at Christian funerals and people who have such funeral culture.

GRANDMA (To the
MUSICIAN) Honey, do you play
all this part? (The MUSICIAN
nods.) Well, keep it nice and
soft; that's good boy. (The
MUSICIAN nods again; play
softly.) That's nice.

\section{The symbol of The Young Man as the Angel of the Death of Grandma}

Never felt love again since her husband died, even though she lived with her child in the city, especially she had never been loved and treated properly by her own child. it gives her affection to grandma. He drew grandma's life with tenderness, kissing his forehead. At least grandma got a little love from the young man even though after that he died. The following fragment of dialogue can explain more about the explanation above.

\section{YOUNG MAN (prepares; delivers the line lika e real amateur). I am the Angel of Death. I am . . uh . . I am come for you.}

GRANDMA. What. ..wha ..(then, with resignation). . . ohhhh. . . ohhhh, I see. (The YOUNG MAN bends over, kisses GRANDMA gently on the forehead.) GRANDMA (her eyes closed, her hands folded on her breast again, the shovel between her hands, a sweet smile on her face). Well. . that was very nice, dear. .

\section{CONCLUSION}

After conducting research in the sandbox drama the authors conclude that:

1. Absurdism is a philosophical term for a genre of modern drama that overhauled systematic traditional drama. An absurd drama is a drama which is full of impossibility, strangeness, sadness, sadness, dark life, emptiness of the actor who plays his role, as well as the voidness of meaning for his stage.

2. The Sandbox is an absurd drama written by Edward Albee. The author has analyzed and described the research objectives in this study. Like drama in general, this drama has supporting elements such as extrinsic elements

3. The flow in absurd dramas is generally irregular. In this absurd drama, the plot can be analyzed according to the rules at the beginning, middle and end. Although still using absurd drama standards where it does not groove.

The stage setting, which consists of only a few supporting elements, symbolizes each character who uses it, such as two empty chairs that illustrate the life of a couple Mommy and Daddy's household life, and a sandbox symbolizing a coffin. The setting is also on the beach, which is absurd because holding a funeral on the beach is not uncommon. The characters in absurd dramas are very limited. In The Sandbox there are five figures, the protagonist is Grandma, the flat figure who does not experience development is Mommy, Daddy, and The Musician, the dynamic character is The Young Man, because he experiences character development. Sub text/stage directives in this drama are clearly listed in the script, to make it easier for the reader or player to know what blocking will be done by the player.

The symbols in this drama correlate with absurdism. Each symbol has its own meaning that represents every movement, behavior, and character of the person playing it. In this drama, an absurd drama that shows the beauty and tenderness of death and is conveyed with humor. Besides carrying out the themes that are characteristic of the absurd drama above, The Sandbox also contains some symboli. Referring to the setting of the stage, the plot, the dialogue that is often unsustainable between actors and the gestures played by them, shows the contrast to the absurd drama that previously always carried the theme of darkness. This drama has been successfully applied by Edward Albee as an absurd version of his drama. 
Drama that contradicts emptiness, nothingness in life, improper treatment of parents where in this drama the excitement that is hidden in sadness ends with a happy story from a different perspective for each actor. Several things related to absurd drama appear in this drama, as the writer has described the supporting elements of absurd drama. This drama leads us to think carefully about the environment around us, especially those related to the story in the drama The Sandbox. The use of symbols related to absurdism reinforces the typical order of absurd drama that is difficult to understand. In conclusion, these are the things that support the success of Albee's absurd meaning in a short drama called The Sandbox. As the author has explained in the chapter discussion about the supporting elements in absurd drama.

Research on the literature of the drama genre has not been studied much ike prose and poetry. The existence of drama is better known by the public as a literary work to be demonstrated, not for analysis.Whereas as a literary genre, drama texts other than to be displayed can also be material for analysis. There drama is still wide open. This is also what the author experienced when taking research material in the form of drama. Drama entitled sandbox, which is carefully discussed by the author, is a matter of absurd drama which also includes symbolism in it which also has deep meaning.

Drama written by Edward Albee also has a very be drama must be known to everyone.As material for drama research, it can be examine using several approaches to analyze what is contained in the drama. In addition, research on drama can also be used as a means to improve in sight in the field of literature. Research on drama needs to be improved, so that the drama can be in line with the iterary genre of prose and poetry as literary works that can be enjoyed. Not only as a form of performance on the stage, but also can be analyzed for the readers. 


\section{Bibliography}

[1]Barthes,Roland. 2012. Semiotic Elements. [10]Nurgiyanto.1994. Symbols. Yogyakarta : Yogyakarta : IRCiSod Hanindita Graha Widya

[2]Beacham. 2007. Absurdisme. Jakarta Gramedia Pustaka Utama

[3]Chandler, Daniel. 2007. Semiotics : The Basic. New York : Routledge. Buku Elektronik

[4]Harsono, Siswo. 2002. Absurdisme in the Avant Garde book. Pustaka Yogyakarta

[5]Kridalaksana, Harimurti. Metalanguage. Jakarta : Gramedia Pustaka Utama

[6]Kanzunnudin.2003. Dictionary of Drama Terms. Rembang:Yayasan Adhigama

[7Kurniawan. 2001. Semiologi Roland Barthes. Magelang : Indonesiatera

[8]Luxemburg, Jan Van dkk. 1995. Introduction of Literature. Jakarta : Gramedia

[9]Moleong.2005.Qualitative Research Methods. PT.Remaja Rosdakarya Bandung

11]Pradopo. 2002. Modern Literary Criticism. Yogyakarta : Gama Media

[12]Putri, Anindya. 2012. Absurdisme and Symbol in drama. Universitas Diponegoro.

https://ejournal3.undip.aca.id(Lantern2012 2 at $1: 30 \mathrm{pm}$

[13]Santoso, puji. 2013. Semiotics and Literary Studies. Bandung :Angkasa

[14]Sudjiman. 1991. Semiotics. Jakarta : Gramedia Pustaka Utama

[15]Sugiyono. 2011. Qualitative Research Methods. Bandung : Afabeta

[16]Sumawijaya, Bambang. 2008. Semiotics Theory an Introduction. Yogyakarta : Jendela

[17]Wellek and Werren. 1990. Literary Theories. Jakarta : Gramedia 